Gut, 1961, 2, 51

\title{
Framycetin sulphate (Soframycin) as a pre-operative bowel-sterilizing agent
}

\author{
A. G. HORSBURGH
}

From the Gordon Hospital, London

SYNOPSIS The author has investigated the bowel-sterilizing powers of framycetin sulphate, and has compared its potency with that of neomycin. He has found that the drug is well tolerated, and not toxic in doses which are sufficient to suppress faecal organisms satisfactorily.

In recent years the use of bowel-sterilizing agents has greatly facilitated gastrointestinal surgery, especially that of the large bowel. Given preoperatively and combined with a course of bowel irrigation an operation field is obtained which is free from faecal contamination and where the faecal organisms are eradicated or greatly reduced in number. A number of chemotherapeutic agents and antibiotics have been tried. The sulphonamides and neomycin have been amongst those most widely used. The sulphonamides require a prolonged course of four or five days to be effective and are therefore not suitable where rapid sterilization is required. Neomycin is an effective agent for quick sterilization and good results may be obtained in 24 hours. The purpose of this paper is to report a clinical trial of a new sterilizing agent, framycetin sulphate (Soframycin), and to compare its effectiveness with that of neomycin.

Framycetin was isolated by Decaris in 1947. It is a broad-spectrum antibiotic affecting both Grampositive and Gram-negative bacteria. It is both bactericidal and bacteriostatic. It has already been used as a local application in the treatment of infected wounds, skin infections, lung abscess, and in bladder irrigation. It has also been used to treat gastrointestinal infection and to prepare the bowel for operation. It is poorly absorbed when given by mouth and is not toxic. Large doses, however, produce nausea and vomiting. It should not be used parenterally as there is a danger of toxic action on the eighth cranial nerve and on the kidney.

\section{METHOD}

The following trial has been carried out on a wide variety of cases coming to intestinal surgery. Among the cases are included gut resections for carcinoma, diverticulitis, ulcerative colitis, Crohn's disease, closure of colostomy, and all but acute cases of intestinal obstruction. In many of these cases the bowel was also treated pre-operatively by lavage.

Three stool cultures were made in each case: (1) preoperatively before administration of the sterilizing agent; (2) at operation from the transected bowel; and (3) postoperatively from the first stool passed.

Four different dosages of Soframycin were used, each dose being given to a group of 12 patients.

Group $1,1 \frac{1}{2} \mathrm{~g}$. twice daily for 24 hours, in a total dosage of $3 \mathrm{~g}$. Group 2, $2 \mathrm{~g}$. twice daily for 24 hours in a total dosage of $4 \mathrm{~g}$. Group 3, $1 \frac{1}{2} \mathrm{~g}$. twice daily for 48 hours in a total dosage of $6 \mathrm{~g}$. Group 4, $1 \mathrm{~g}$. hourly for four hours, then $1 \mathrm{~g}$. four hourly for 20 hours in a total dosage of $9 \mathrm{~g}$.

The results in these four groups were compared with those of another group of 25 patients who received neomycin pre-operatively. The dose of neomycin used was the same as for group 4 receiving Soframycin, i.e., $1 \mathrm{~g}$. hourly for four hours, then $1 \mathrm{~g}$. four hourly for 20 hours. This dose of Neomycin is the standard used as a preoperative bowel sterilizing agent for some time now. At these dosage levels of Soframycin no toxic signs were met except in group 4 where a total of $9 \mathrm{~g}$. was given in 24 hours. Nausea and vomiting occurred in over $60 \%$ of cases and the drug had to be stopped. With a similar dose of Neomycin nausea and vomiting occurred more rarely. With the lower doses of Soframycin, however, the drug is very well tolerated. Patients who at different times had received Soframycin and Neomycin often express a perference for Soframycin as it causes less discomfort from intestinal hurry.

RESULTS

Of the 12 patients in group 1 (Soframycin $3 \mathrm{~g}$. in $24 \mathrm{hr}$.) five had no bacteria in the stool at operation. One of these stools contained yeasts. In the first post-operative stool bacteria were present in all but one patient.

In Group 2 (Soframycin $4 \mathrm{~g}$. in $24 \mathrm{hr}$.) eight out of 12 patients had bacteria-free stools at operation. A further patient produced only a scanty growth. 
In the first post-operative stool bacteria were present in all but three cases, one of these containing yeasts.

In group 3 (Soframycin $6 \mathrm{~g}$. in $48 \mathrm{hr}$.) eight out of 12 patients had bacteria-free stools at operation, one of these containing yeasts. A further two patients produced only a scanty growth. In the first post-operative stool bacteria were present in all but two.

In group 4 (Soframycin $9 \mathrm{~g}$. in $24 \mathrm{hr}$.) only four of the 12 patients tolerated the whole dose. The other eight patients vomited some of their tablets. Of these four, three had bacteria-free stools at operation. In the first post-operative stool bacteria were present in all but one.

Of the 25 patients on Neomycin (Neomycin $9 \mathrm{~g}$. in $24 \mathrm{hr}$.), 17 produced a bacteria-free stool at operation. Of these five contained yeasts. A further two patients produced only a scanty growth. In the first post-operative stool seven patients were free from bacteria. Of these one contained yeasts. A further one produced only a scanty growth.

Further analysis of these figures is shown in Table I. It may be seen that Soframycin in dosages

TABLE I

ANALYSIS OF RESULTS WITH SOFRAMYCIN AND NEOMYCIN

\begin{tabular}{|c|c|c|c|c|}
\hline Soframycin (g.) & $\begin{array}{l}\text { Total } \\
\text { Dose } \\
\text { (g.) }\end{array}$ & $\begin{array}{l}\text { No. of } \\
\text { Cases }\end{array}$ & $\begin{array}{l}\text { No. with } \\
\text { Positive } \\
\text { Stool } \\
\text { Culture at } \\
\text { Operation }\end{array}$ & $\begin{array}{l}\text { No. with } \\
\text { Negative } \\
\text { Stool } \\
\text { Culture at } \\
\text { Operation }\end{array}$ \\
\hline \multirow{2}{*}{ 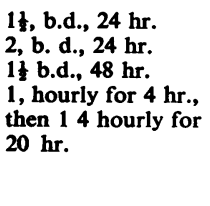 } & $\begin{array}{l}3 \\
4 \\
6\end{array}$ & $\begin{array}{l}12 \\
12 \\
12\end{array}$ & $\begin{array}{l}7 \\
4 \\
4\end{array}$ & $\begin{array}{l}5(38 \%) \\
8(66 \%) \\
8(66 \%)\end{array}$ \\
\hline & 9 & $\begin{array}{l}4 \\
\text { Test } \\
\text { abandoned }\end{array}$ & 1 & $3(75 \%)$ \\
\hline $\begin{array}{l}\text { Neomycin } \\
1 \text { hourly for } 4 \mathrm{hr} \text {. } \\
\text { then } 14 \text { hourly for } \\
20 \mathrm{hr} \text {. }\end{array}$ & 9 & 25 & 8 & $17(68 \%)$ \\
\hline
\end{tabular}

of $4 \mathrm{~g}$. in $24 \mathrm{hr}$. or $6 \mathrm{~g}$. in $48 \mathrm{hr}$. produces negative stool culture at operation in $66 \%$ of cases. This compares very closely with Neomycin where the figure is $68 \%$. In a dosage of $3 \mathrm{~g}$. Soframycin in $24 \mathrm{hr}$., however, the figure falls to $38 \%$. At a dosage of $9 \mathrm{~g}$. Soframycin in $24 \mathrm{hr}$. stool culture was negative at operation in $75 \%$ of patients who tolerated the drug. However, this cannot be regarded as a useful dose owing to vomiting, and the number of cases tolerating the drug is too small to be significant.

It was noted that apart from patients showing negative stool culture and scanty growth at operation, nearly all at all dosages showed a considerable reduction in the bacterial content of the stool. This was true both for Soframycin and Neomycin.

In those patients on Soframycin showing positive stool culture at operation, streptococci were found most often. Ps. pyocyonea was the next most frequent organism found, then coliforms, Proteus, $\mathrm{Cl}$. Welchii, and Staph. albus in order of decreasing frequency.

In cases showing negative stool culture at operation yeasts occurred from time to time both with Soframycin and Neomycin.

\section{DISCUSSION}

From the results above it would appear that Soframycin is a useful bowel-sterilizing agent. It causes a marked reduction in the organisms in the stool, and when given in optimum dosage produces a sterile stool at operation in $66 \%$ of cases. The length of preoperative medication to produce these results is short and the drug is well tolerated except in very high dosage. Results compare very closely with those for Neomycin but dosages required are lower and patients do not complain of intestinal hurry. Dosage of $1 \frac{1}{2} \mathrm{~g}$. twice daily for 48 hours or $2 \mathrm{~g}$. twice daily for 24 hours produces good results. At no time were any toxic reactions noticed, but at higher doses some nausea and vomiting was produced.

\section{SUMMARY}

Framycetin sulphate (Soframycin) has been tried as a pre-operative bowel-sterilizing agent, and results have been compared with those for Neomycin.

Faecal organisms have been well suppressed at doses of $4 \mathrm{~g}$. to $6 \mathrm{~g}$. given over 24 to 48 hours.

The drug is well tolerated and is not toxic.

Very little intestinal hurry is produced.

Nausea and vomiting may occur at higher doses.

I should like to thank Mr. A. Lawrence Abel for help with this paper, members of the surgical staff of the Gordon Hospital on whose patients the trial was carried out, Dr. W. M. Edgar for his work on the bacteriology, and Roussel for supplying the Soframycin.

\section{BIBLIOGRAPHY}

Burrows, D. (1958). Brit. med. J., 2, 428-429.

Connell, J. F., and Rousselot, L. M. (1958). Surgery, 44, 447-452.

Decaris, L. J. (1953). Ann. pharm. franc., 11, 44-46.

Fairbrother, R. W., and Williams, B. L. (1958). Lancet, 2, 1353-1355.

Louwette, R., and Lambrechts, A. (1958). Brit. med. J., 1, 868-869.

Maccebe, A. F. (1959). Practitioner, 182, 628-634.

Shidlovsky, B. A., Marmell, M., and Prigot, A. (1956). Antibiotics Annual, 1955-1956, p. 118-121. 